\title{
Call for Application from Indian Geoscientists for the B.P. Radhakrishna Travel Grant
}

The Geological Society of India has instituted the B.P. Radhakrishna Travel Grant to encourage young Indian Geoscientists (35 years of age) for participation in the International Seminars. Applications are invited by scientists whose abstract has been accepted for presentation at the $35^{\text {th }}$ International Geological Congress (IGC) during 27 August to 4 September 2016 at Cape Town, South Africa. The applicant should be the corresponding author and the last date for submission of application is $30^{\text {th }}$ June 2016.

The following information should be provided by the applicant

1. Bio-data including phone and cell no., email address with 2 passport size photographs.

2. List of publications

3. Letter of acceptance of the abstract submitted to $35^{\text {th }}$ IGC

4. Copy of High School Certificate or any other document indicating the age is below 35 years.

The application for the grant should be sent to the Secretary, Geological Society of India, 63, Basappa Layout, Gavipuram Extension, Bangalore - 560 019. Phone: 080-26613352; Email: gsocind@gmail.com

\section{Field Training for Graduate/Postgraduate Geology Teachers}

The Geological Society of India, Bengaluru will be organizing Prof. G.H.Sawkar endowment training programme on "Field Techniques in Geological Mapping and Exploration" in the month of June, 2016. The training programme is meant for the faculty teaching graduate/postgraduate students in the field of Geology and will be for one week duration. The details of the programme will be posted in the Society website: www.geosocindia.org. Interested teachers may contact Secretary, Geological Society of India, 63, Basappa Layout, Gavipuram Extension, Bangalore - 560 019. Phone: 080-2661 3352; Email: gsocind@gmail.com

\footnotetext{
"Printed by M. Nagaraju and Published by R.H. Sawkar on behalf of the Geological Society of India, No.63, 12 ${ }^{\text {th }}$ Cross, Basappa Layout, Gavipuram, Bengaluru - 560019 and Printed at M/s Driti Enterprises, No.117/19. Cauverynagar Main Road, B.S.K. $3^{\text {rd }}$ Stage, Bengaluru -560085 and Published at the Geological Society of India, No.63, 12 ${ }^{\text {th }}$ Cross, Basappa Layout, Gavipuram, Bengaluru - 560 019” - Editor: B. Mahabaleswar.
} 